\title{
OdPOWIEDZIALNOŚĆ PRAWNA PRODUCENTÓW ZA SZKODĘ WYRZĄDZONĄ PRZEZ PRODUKT NIEBEZPIECZNY w Orzecznictwie Trybunaeu Sprawiedliwości \\ I PRAWIE POLSKIM
}

\section{Wprowadzenie}

Dnia 25 lipca 1985 r. Rada Wspólnot Europejskich przyjęła dyrektywę 85/374/EWG w sprawie zbliżenia przepisów ustawowych, wykonawczych i administracyjnych państw członkowskich dotyczących odpowiedzialności za produkty wadliwe (zwana dalej: dyrektywa 85/374/EWG)1, która została implementowana do krajowych porządków prawnych członków Europejskiej Wspólnoty Gospodarczej, a obecnie Unii Europejskiej (zwana dalej: UE). Na mocy przepisów prawnych zawartych we wspomnianej dyrektywie, Europejski Trybunał Sprawiedliwości - obecnie Trybunał Sprawiedliwości (zwany dalej: Trybunat) wydał szereg orzeczeń, których tezy rozstrzygnięć oddziałują w sposób zasadniczy na linię orzeczniczą sądów krajowych - członków Unii Europejskiej (case law),a w tym również na orzecznictwo sądów polskich. Dla celów przedmiotowej analizy, zostały wybrane trzy charakterystyczne wyroki prejudycjalne Trybunału, określające zakres odpowiedzialności prawnej (odszkodowawczej) producentów oraz dystrybutorów wyrobów medycznych i środków farmaceutycznych za wytworzone bądź dostarczane przez nich produkty, które zostały wprowadzone na rynek unijny, a swoim „,wadliwym” działaniem wyrządziły szkodę. Orzeczenia, które zostały poddane analizie to:

* Mgr, Uniwersytet Śląski; jaroslaw.kocot@onet.eu.

${ }^{1}$ Dyrektywa Rady 85/374/EWG z dnia 25 lipca 1985 r. w sprawie zbliżenia przepisów ustawowych, wykonawczych i administracyjnych Państw Członkowskich dotyczących odpowiedzialności za produkty wadliwe Dz. Urz. UE L 210, z 1985 r., poz. 29. 
1) Wyrok Trybunału z dnia 4 czerwca 2009 r., w sprawie o sygn. akt: C-285/08 pomiędzy Moteurs Leroy Somer przeciwko Dalkia France i Ace Europe²,

2) Wyrok Trybunału z dnia 2 grudnia 2009 r., w sprawie o sygn. akt: $\mathrm{C}-358 / 08$, pomiędzy Aventis Pasteur SA przeciwko OB ${ }^{3}$,

3) Wyrok Trybunału z dnia 21 grudnia 2011 r., w sprawie o sygn. akt: C-495/10, pomiędzy Centre Hospitalier Universitaire de Besançon przeciwko Thomasowi Dutrueux'mu. ${ }^{4}$

Celem artykułu jest wskazanie wpływu wyżej wymienionych orzeczeń prejudycjalnych Trybunału Sprawiedliwości na orzecznictwo sądów polskich w zakresie stosowania implementowanej dyrektywy 85/374/ EWG do polskiego porządku prawnego.

Należy podkreślić, że od wczesnych lat siedemdziesiątych XX wieku, instytucje oraz organy Europejskiej Wspólnoty Gospodarczej wskazywały, że trzeba podjąć konkretne działania ustawodawcze mające na celu ujednolicenie przepisów prawnych dotyczących określenia zakresu odpowiedzialności prawnej (odszkodowawczej) producenta produktu, który wadliwym działaniem wyrządził szkodę. Wspomniane sugestie wynikały z kilku faktów, a tj. m.in. każde państwo członkowskie Unii Europejskiej w sposób odmienny regulowało kwestie odpowiedzialności prawnej za szkodę wyrządzoną przez produkt wadliwy (niebezpieczny) bądź też z niemożliwością „pociągnięcia” do odpowiedzialności odszkodowawczej podmiotu gospodarczego z siedzibą poza granicami Unii Europejskiej, który wprowadził sam bądź poprzez dystrybutora produkt na rynek unijny, a którego wadliwe działanie spowodowało powstanie szkody na terytorium Unii. Ostatecznie dokumentem regulującym wskazaną materię była przyjęta w dniu 25 lipca 1985 roku - Dyrektywa Rady 85/374/EWG w sprawie zbliżenia przepisów ustawowych, wykonawczych i administracyjnych państw członkowskich dotyczących odpowiedzialności za produkty wadliwe, która wprowadziła do ustawodawstw państw Wspólnoty ujednolicone przepisy prawne ułatwiające dochodzenie odszkodowania od podmiotów gospodarczych, wprowadzających produkt „wad139354.

${ }^{2}$ Wyrok Trybunału z dnia 4 czerwca 2009 r., w sprawie o sygn. akt: C - 285/08, Legalis

${ }^{3}$ Wyrok Trybunału z dnia 2 grudnia 2009 r., w sprawie o sygn. akt: C - 358/08, LEX Dz.U.UE.C.2010.24.11.

${ }^{4}$ Wyrok Trybunału z dnia 21 grudnia 2011 r., w sprawie o sygn. akt: C - 495/10, LEX Dz.U.UE.C.2012.49.11/2 . 
liwy" - w rozumieniu art. 2 w związku z art. 6 dyrektywy 85/374/EWG na rynek unijny. Jej przygotowanie i przyjęcie było poprzedzone blisko dziesięcioletnim okresem wytężonej pracy legislacyjnej. Podobnie długi był również „okres implementacyjny” przedmiotowej dyrektywy do porządków prawnych członków Unii Europejskiej. Ostatnim państwem, które to uczyniło, była Francja, wdrożywszy wspomniane postanowienia dopiero w 1999 r. $^{5}$

Pomimo upływu 30 lat od uchwalenia Dyrektywy 85/374/EWG, była ona tylko raz "nowelizowana”, a tj. w dniu 10 maja 1999 roku - Dyrektywą 1999/34/WE Parlamentu Europejskiego i Rady ${ }^{6}$. W związku z czym, należy stwierdzić, że jej postanowienia pozostają wciąż aktualne, pomimo postępu technologicznego oraz rozwoju gospodarczego członków Unii Europejskiej. Przepisy dyrektywy 85/374/EWG mają charakter uniwersalny, co umożliwia jej stosowanie do wielu produktów wprowadzanych na rynek unijny, a w tym również do wyrobów medycznych i środków farmaceutycznych. W pracy została wykorzystana metoda dogmatyczno prawna i prawno - porównawcza.

Rzeczpospolita Polska dokonując w 2004 r. akcesji do Unii Europejskiej, została zobowiązana do przyjęcia dorobku ustawodawczego i orzeczniczego „Wspólnoty”, a w tym również do implementacji „znowelizowanej” dyrektywy 85/374/EWG. Przepisy prawne dotyczące odpowiedzialności za szkodę wyrządzoną przez produkt niebezpieczny zostały wprowadzone do polskiego Kodeksu cywilnego ${ }^{7}$, w postaci art. $449^{1}-449^{11}$ k.c. na mocy ustawy z dnia 2 marca 2000 roku o ochronie niektórych praw konsumentów oraz o odpowiedzialności za szkodę wyrządzoną przez produkt niebezpieczny ${ }^{8}$

Należy zwrócić uwagę, że dyrektywa 85/374/EWG posługuje się pojęciem produkt wadliwy, a polski ustawodawca dokonując implementacji

${ }^{5}$ A. Łazowski, Ogólne bezpieczeństwo i odpowiedzialność za produkt wadliwy, Warszawa, 2001, s. 7.

${ }^{6}$ Dyrektywa 1999/34/WE Parlamentu Europejskiego i Rady z dnia 10 maja 1999 r. zmieniająca dyrektywę Rady 85/374/EWG sprawie zbliżenia przepisów ustawowych, wykonawczych i administracyjnych Państw Członkowskich dotyczących odpowiedzialności za produkty wadliwe, Dz. Urz. UE. L. z 1999 r., Nr 141, poz. 20.

7 Ustawa z dnia 23 kwietnia 1964 r. - Kodeks cywilny, Dz.U. Nr 16, poz. 93 z późn. zm.

8 Ustawa z dnia 2 marca 2000 roku o ochronie niektórych praw konsumentów oraz o odpowiedzialności za szkodę wyrządzoną przez produkt niebezpieczny, Dz. U. 2000, Nr 22, poz. 271 z późn. zm.. 
przepisów ww. aktu, posłużył się pojęciem produktu niebezpiecznego, aczkolwiek są to tożsame sformułowania. $Z$ tego powodu - w treści artykułu wspomniane pojęcia będą stosowane wymiennie. Trzeba również pamiętać, że polski ustawodawca, przed implementacją dyrektywy 85/374/EWG posługiwał się pojęciem towar niebezpieczny ${ }^{9}$. W aktualnym porządku prawnym pomiędzy towarem niebezpiecznym, a produktem niebezpiecznym (wadliwym) można postawić znak równości. Trzeba w związku z tym zauważyć, że w implementowanej regulacji stanowi się zatem o wadliwości produktu (i to nie tylko w jej tytule, ale i konsekwentnie $w$ całej jej treści), a nie o jego niebezpieczeństwie, jak ma to miejsce $\mathrm{w}$ polskim Kodeksie cywilnym. W literaturze przedmiotu tę rozbieżność terminologiczną tłumaczy się tym, że odwołanie się w ramach kodeksu do pojęcia produktu niebezpiecznego, a nie wadliwego, miało na celu systemowe dopasowanie wprowadzanych przepisów do regulacji już obowiązujących $\mathrm{w}$ polskim prawie cywilnym, $\mathrm{w}$ tym zwłaszcza uniknięcie potencjalnego sugerowania ich związku z odpowiedzialnością z tytułu rękojmi lub gwarancji ${ }^{10}$.

\section{Wyrok Trybunału z dnia 4 czerwca 2009 roku, w sprawie o sygn. akt: C - 285/08 ${ }^{11}$}

\section{1.) Stan faktyczny rozpoznawanej sprawy i stawiane pytanie:}

$W$ nastęstwie przegrzania sie alternatora wyprodukowanego przez Moteurs Leroy Somer i wprowadzonego przez tę spótkę do obrotu w 1994 r. doszło do pożaru zespołu pradotwórczego uruchomionego w 1995 r. przez spótke Wartsila w szpitalu w Lyon. Dalkia France, zajmujaca się konserwacja tego zespołu i jej ubezpieczyciel Ace Europe naprawili szkody majatkowe, jakie ponióst szpital w wyniku tego wypadku, a następnie wstapili w jego prawa $i$ wytoczyli Moteurs Leroy Somer powództwo o zwrot zapłaconych kwot. W wyroku

9 Wyrok SN z dnia 6 lipca 1981 r., I CR 219/81, LEX 2711.

10 E. Łętowska, Ochrona niektórych praw konsumentów. Komentarz, Warszawa 2001, s.121; C. Żuławska, [w:] G. Bieniek, H. Ciepła, S. Dmowski, J. Gudowski, K. Kołakowski, M. Sychowicz, T. Wiśniewski, C. Żuławska (red.), Komentarz do kodeksu cywilnego. Księga trzecia. Zobowiąania, Warszawa 2011, tom 1, s. 707.

${ }^{11}$ Sprawa pomiędzy Moteurs Leroy Somer przeciwko Dalkia France i Ace Europe, a dotycząca naruszenia art. 9 i art. 13 dyrektywy 85/374 EWG - odpowiedzialność za produkty wadliwe. 
$z$ dnia 7 grudnia 2006 r. sad apelacyjny w Lyon stwierdzit, że Moteurs Leroy Somer była zobowiazana do zapewnienia bezpieczeństwa i nakazał jej zapłate kwoty 320 143,03 EUR na rzecz Dalkia France i kwoty 229107 EUR na rzecz Ace Europe. Spótka Moteurs Leroy Somer podnosi przed sadem krajowym w szczególności, że obowiazek zapewnienia bezpieczeństwa, cią̇acy na wszystkich podmiotach zawodowo zajmujących się sprzedaża, nie obejmuje szkód na rzeczach przeznaczonych do użytku profesjonalnego $i$ używanych przez poszkodowanego w celach profesjonalnych. Nakazujac jej naprawienie czysto materialnych szkód zespołu prądotwórczego, zamówionego przez szpital dla potrzeb prowadzenia działalności profesjonalnej, sad apelacyjny w Lyon naruszyt postanowienia art. 1603 code civil (kodeksu cywilnego), w wykładni dokonywanej w świetle dyrektywy 85/374 - treść orzeczenia Trybunału z dnia z dnia 4 czerwca 2009 roku, sygn.: C - 285/08.

Cour de cassation (Francja) uznał, że dla wydania rozstrzygnięcia w przedmiocie wniesionej do niego skargi kasacyjnej niezbędne jest dokonanie wykładni dyrektywy 85/374/EWG, dlatego postanowił zawiesić postępowanie i przedłożyć Trybunałowi następujące pytanie prejudycjalne:

„czy art. 9 i 13 dyrektywy [85/374] stoją na przeszkodzie takiej wykładni prawa krajowego lub utrwalonego orzecznictwa krajowego, która umożliwia poszkodowanemu żądanie naprawienia szkody na rzeczy przeznaczonej do użytku profesjonalnego i używanej zgodnie z przeznaczeniem, jeśli poszkodowany wykaże tylko wystąpienie szkody, wadę produktu oraz związek przyczynowy między wadą a szkodą?".

\section{2.) Streszczenie wyroku Trybunału:}

Wykładni dyrektywy Rady 85/374/EWG z dnia 25 lipca 1985 r. w sprawie zbliżenia przepisów ustawowych, wykonawczych i administracyjnych państw członkowskich dotyczących odpowiedzialności za produkty wadliwe należy dokonywać w ten sposób, że nie stoi ona na przeszkodzie takiej wykładni prawa krajowego lub stosowaniu utrwalonego orzecznictwa krajowego, które umożliwiają poszkodowanemu żądanie naprawienia szkody na rzeczy przeznaczonej do użytku profesjonalnego i używanej zgodnie z przeznaczeniem, jeśli wykaże on jedynie istnienie szkody, wady produktu oraz związku przyczynowego między nimi ${ }^{12}$.

12 Pełna treść wyroku Trybunału z dnia 4 czerwca 2009 r., C - 285/08 - dostępna na: http://curia.europa.eu/juris/celex.jsf?celex=62008CJ0285\&lang1=pl\&type=TXT\&ancre= 


\section{3.) Komentarz:}

Przedmiotem rozważań Trybunału w niniejszej sprawie, było udzielenie odpowiedzi, czy postanowienia dyrektywy 85/374/EWG mogą mieć zastosowanie $\mathrm{w}$ celu przypisania odpowiedzialności odszkodowawczej producentowi produktu wadliwego za jego wyprodukowany towar, który wyrządził szkodę na rzeczach przeznaczonych do użytku profesjonalnego, a używanych zgodnie $\mathrm{z}$ ich przeznaczeniem. Na wstępie należy wskazać, że alternator szpitalny jest zaliczany do kategorii produktów, co do których ma zastosowanie przedmiotowa dyrektywa. Wynika to z treści art. 2 dyrektywy 85/374/EWG, który w sposób następujący definiuje produkt, jakim jest "każda rzecz ruchoma, z wyjatkiem surowców rolnych i produktów łowiectwa, nawet będąca częścia składowa innej rzeczy ruchomej lub nieruchomej. "Surowce rolne" oznaczaja produkty ziemi, hodowli, rybołówstwa, z wyłaczeniem produktów poddanych wstępnemu przetworzeniu. "Produktem" jest również elektryczność." Pojęcie „wadliwości” produktu zostało określone w art. 6 dyrektywy 85/374/EWG. Przechodząc do analizy przedmiotowego orzeczenia należy wskazać, że treść art. 1 dyrektywy 85/374/EWG daje podstawę do przypisania odpowiedzialności prawnej producentowi, który ponosi odpowiedzialność za szkode wyrządzona przez wytworzony przez niego wadliwy produkt. Definicja legalna pojęcia szkody została przedstawiona w art. 9 dyrektywy 85/374/EWG:

„szkoda oznacza:

a) szkodę spowodowana przez śmierć lub przez uszkodzenia ciała,

b) uszkodzenie lub zniszczenie każdej rzeczy innej niż produkt wadliwy o wartości powyżej 500 ECU, pod warunkiem że rzecz ta:

- jest zwykle przeznaczona do prywatnego użytku lub konsumpcji; $i$

- była używana przez osobe poszkodowana głównie dla jej prywatnego użytku lub konsumpcji."

Niewątpliwym jest fakt, że zgodnie z treścią art. 9 pkt a dyrektywy 85/374/EWG, dyrektywa ta ma zastosowanie do szkód powstałych na osobie, których skutkiem była śmierć bądź uszkodzenie ciała. W związku z powyższym, poszkodowany na etapie postępowania sądowego musi udowodnić powstałą stratę, wadę produktu oraz związek przyczynowy pomiędzy wspomnianą wadą a powstałą szkodą. Sytuacja jest bardziej skomplikowana, gdy uszkodzeniu uległa rzecz materialna. Zgodnie z treścią art. 9 pkt b dyrektywy 85/374/EWG, poszkodowany jest uprawniony do uzyskania rekompensaty za szkodę powstałą na rzeczy, acz- 
kolwiek, żeby powstała taka możliwość - uszkodzeniu lub zniszczeniu musi ulec rzecz inna niż produkt wadliwy, a wartość powstałej szkody przewyższa obecnie kwotę 500,00 euro. Ponadto odpowiedzialność za szkodę na mieniu, wyrządzoną przez produkt niebezpieczny jest ograniczona do sytuacji, gdy rzecz, która uległa zniszczeniu lub uszkodzeniu należała do rzeczy zwykle przeznaczanych do osobistego użytku, a poszkodowany korzystał z niej głównie w taki sposób. Podstawowym środkiem dowodowym $\mathrm{w}$ postępowaniu dotyczącym odpowiedzialności za szkodę wyrządzoną przez produkt niebezpieczny powinna być opinia powołanego biegłego, gdyż zgodnie z treścią art. 4 dyrektywy 85/374/EWG to na osobie poszkodowanej spoczywa ciężar udowodnienia szkody, wady i zwiazku przyczynowego między wada a szkoda. Trzeba zwrócić uwagę, że w art. 9 dyrektywy 85/374/EWG zostało użyte sformułowanie "przeznaczone do prywatnego użytku lub konsumpcji”, co jest pojęciem nieostrym. Polski ustawodawca w treści art. $449^{2}$ k.c. posłużył się zwrotem "użytku osobistego" to również takowe sformułowanie, powoduje spore trudności interpretacyjne, gdyż trudno jest ustalić granicę pomiędzy użytkowaniem osobistym, a użytkowaniem pozbawionym charakteru osobistego. Przechodząc do istoty przedmiotowego orzeczenia, wypada podkreślić, że Trybunał wskazał, że brak jest podstaw prawnych do stosowania postanowień dyrektywy 85/374/EWG w sytuacji, gdy zniszczeniu bądź uszkodzeniu uległa rzecz, która była przeznaczona do użytku profesjonalnego, a nadto była używana zgodnie z jej przeznaczeniem. Polskie orzecznictwo oraz judykatura wypracowały tożsame stanowisko w powyższej kwestii, gdyż wskazuja, że „W doktrynie trafnie podkreśla się, że intencja prawodawcy było wyłaczenie spod omawianego reżimu odpowiedzialności szkód majątkowych w odniesieniu do rzeczy przeznaczonych do działalności gospodarczej lub zawodowej, np. pracowniczej odzieży ochronnej". ${ }^{13}$ Należy w związku z tym podkreślić, że również w polskim porządku prawnym nie ma możliwości naprawienia szkody powstałej w reżimie odpowiedzialności za produkt niebezpieczny, gdy dany produkt był używany w sposób prawidłowy i w dodatku przez profesjonalistę. Potwierdza to wyrok Sądu Najwyższego z dnia 4 sierpnia 2005 r., w sprawie o sygn. akt: III CK 701/04 zawierający następującą tezą rozstrzygnięcia: „Nie sposób, nawet jedynie dla celów wykładni, odnosić ustawo-

13 P. Mikłaszewicz, Komentarz do art. 449², [w:] K. Osajda (red.) Kodeks Cywilny. Komentarz. Zobowiazania, t. II, Warszawa 2014, s. 719. 
wego określenia produktu niebezpiecznego do sytuacji, której powód będacy profesjonalista $w$ dziedzinie tynkarstwa nabył materiaty tynkarskie nie stwarzajace żadnego zagrożenia i użył je w sposób niewłaściww, powodując odpadnięcie tynku i szkody w mieniu osób trzecich, które musiał usunać. Prawidłowe, normalne użycie ${ }^{14}$ nabytych materiałów tynkarskich, nie stwarzało żadnego zagrożenia, nie można zatem uznać, nawet stosujac pomocniczo definicje zawarta w art. $449^{1}$ $\S 3$ k.c., że stanowity one produkt niebezpieczny. To zaś prowadzi do wniosku, że na producencie produktu nie cią̇̇y szczególny, wynikający z niebezpiecznego charakteru produktu, obowiazek pouczenia i uprzedzenia nabywców o wszystkich możliwych skutkach jego użycia, w tym także skutkach użycia niewłaściwego. Tym bardziej odnosi się to do sytuacji, gdy chodzi o powszechnie używany preparat sprzedawany do profesjonalnego zastosowania przez doświadczonych fachowców, którzy powinni posiadać odpowiednia wiedzę o jego właściwym użyciu"15.

Konkludując należy zgodzić się z tezą rozstrzygnięcia zawartą w wyroku Trybunału z dnia 4 czerwca 2009 r., w sprawie o sygn. akt: C - 285/08, wskazująca, że dyrektywa 85/374/EWG nie reguluje kwestii naprawienia szkody na mieniu, gdy zniszczona lub uszkodzona rzecz była przeznaczona do użytku profesjonalnego i była używana zgodnie z tym przeznaczeniem. Nie istnieje możliwość stosowania analogii, w celu objęcia surową odpowiedzialnością opartą na zasadzie ryzyka, szkód na mieniu w zakresie użytku profesjonalnego, aczkolwiek każde państwo ma możliwość wprowadzenia do swojego porządku prawnego, przepisów prawnym, które umożliwią zastosowanie innej odpowiedzialności np. typu deliktowego niezależnie od winy.

\section{Wyrok Trybunału z dnia 2 grudnia 2009 r., w sprawie o sygn. akt: $C-358 / 08^{16}$}

\section{1.) Stan faktyczny rozpoznawanej sprawy i stawiane pytanie:}

Przedmiotowa sprawa dotyczyła małoletniego, który w przychodni w Zjednoczonym Królestwie szczepionkę zawierająca substancję czynna HIB, której pro-

${ }^{14}$ Znaczenie pojęcia „normalne użycie” zostało wyjaśnione w: B. Gnela, Odpowiedzialność Przedsiębiorców za szkody wyrządzone przez produkt niebezpieczny, [w:] A. Śmieja (red.) Odpowiedzialność cywilna w obrocie gospodarczym, [w:] Prace Naukowe UE we Wrocławiu, Wrocław 2011, nr 2013, s. $44-45$.

${ }_{15}$ Wyrok SN z dnia 4 sierpnia 2005 r., III CK 701/04, LEX 371489.

${ }^{16}$ Sprawa pomiędzy Aventis Pasteur SA przeciwko OB., a dotycząca naruszenia art. 3 i 11 dyrektywy 85/374/EWG - odpowiedzialność za produkty wadliwe. 
ducentem była spótka prawa francuskiego Pasteur Mérieux Sérums et Vaccins S.A. Spótka ta zmieniła następnie nazwę na Aventis Pasteur SA (dalej zwana "APSA"). Dystrybucja szczepionki w Zjednoczonym Królestwie zajmowała się spótka angielska Merieux UK Limited, spótka zależna wobec APSA i całkowicie przez nia kontrolowana. W 1994 r. APSA utworzyła wraz ze spótka Merck Inc spótke joint venture. Merieux UK Limited z kolei stała się spótka zależna wobec tej właśnie spótki joint venture, a następnie zmieniła nazwe na Aventis Pasteur MSD (dalej zwana "APMSD"). W zwiazku z faktem, że wspomniana szczepionka spowodowała u małoletniego ciężkie uszkodzenie mózgu, jego petnomocnik wystapił w dniu 2 listopada 2000 z powództwem o odszkodowanie przeciwko "producentowi" szczepionki Aventis Pasteur MSD , a tj. APMSD, który w odpowiedzi na pozew podnióst, że jest wyłacznie jej dystrybutorem, a producentem jest spótka Pasteur Merieux Serum et Vaccins S.A ("APSA"). W związku z powyższym, petnomocnik małoletniego, w dniu 16 października 2002 r. wystapił z powództwem przeciwko APSA, w którym domagała się odszkodowania w oparciu o uzasadnienie, że APSA jest producentem szczepionki. W ramach tego postępowania APSA przyznała, że jest producentem szczepionki, zwróciła jednak uwage na to, że skierowane przeciwko niej powództwo zostało wniesione po terminie, stwierdzajac, że produkt zostat wprowadzony do obrotu poprzez wysłanie go w dniu 18 września 1992 r. do APMSD, która to otrzymała przesytkę w dniu 22 września, w zwiazku z tym dziesięcioletni termin przedawnienia, przewidziany w art. 11 A ust. 3 Limitation Act 1980 upłynat, jej zdaniem, najpóźniej w dniu 7 października 2002 r.- treść orzeczenia Trybunału z dnia z dnia 2 grudnia 2009 roku, sygn.: C - 285/08.

House of Lords (Zjednoczone Królestwo) złożyła do Trybunału, wniosek o wydanie orzeczenia w trybie prejudycjalnym, w celu wykładni art. 11 dyrektywy Rady 85/374/EWG poprzez udzielenie odpowiedzi na poniższe pytanie prejudycjalne:

"czy i pod jakimi warunkami producent produktu może zostać w drodze wstapienia w miejsce innego podmiotu właczony w charakterze pozwanego do postępowania, w którym poszkodowany dochodził swoich praw przystugujacych mu na podstawie tej dyrektywy btędnie przeciwko dostawcy produktu, jeżeli postępowanie to zostało wszczęte przed uptywem dziesięcioletniego terminu przedawnienia przewidzianego w art. 11 dyrektywy 85/374, natomiast wniosek o dokonanie zmiany po stronie pozwanego został złożony dopiero po upływie tego dziesięcioletniego terminu?" 


\section{2.) Streszczenie wyroku Trybunału:}

Wykładni art. 11 dyrektywy Rady 85/374/EWG z dnia 25 lipca 1985 r. w sprawie zbliżenia przepisów ustawowych, wykonawczych i administracyjnych państw członkowskich dotyczących odpowiedzialności za produkty wadliwe należy dokonać w ten sposób, że sprzeciwia się temu, aby uregulowanie krajowe, które zezwala na zmianę strony pozwanej w toku postępowania sądowego, było stosowane w taki sposób, który pozwala na wstąpienie, po upływie terminu w nim ustanowionego "producenta" w rozumieniu art. 3 tej dyrektywy, w miejsce strony pozwanej do postępowania sądowego wszczętego $\mathrm{w}$ tym terminie przeciwko innemu podmiotowi. Jednakże z jednej strony wykładni omawianego art. 11 należy dokonać w ten sposób, że nie stoi on na przeszkodzie temu, aby sąd krajowy uznał, iż w postępowaniu sądowym wszczętym $\mathrm{w}$ terminie $\mathrm{w}$ nim ustanowionym przeciwko spółce zależnej w $100 \%$ od „producenta” w rozumieniu art. 3 ust. 1 dyrektywy 85/374/EWG producent może wstąpić w miejsce tej spółki, w przypadku gdy sąd stwierdzi, że wprowadzenie do obrotu danego produktu zostało $\mathrm{w}$ rzeczywistości dokonane przez producenta. Z drugiej strony wykładni art. 3 ust. 3 dyrektywy 85/374/EWG trzeba dokonać w ten sposób, że w przypadku gdy poszkodowany zastosowaniem rzekomo wadliwego produktu nie mógł racjonalnie zidentyfikować producenta tego produktu przed podniesieniem swych roszczeń wobec jego dostawcy, wówczas dostawcę wypada uznać za producenta, szczególnie w celu zastosowania art. 11 tej dyrektywy, jeżeli dostawca nie poinformował poszkodowanego z własnej inicjatywy i w staranny sposób o tożsamości producenta lub swego dostawcy. Dokonanie oceny w tym zakresie należy, w świetle danych okoliczności do sądu krajowego ${ }^{17}$.

\section{3.) Komentarz:}

Na wstępie trzeba podkreślić, że europejskie orzecznictwo zalicza środki farmaceutyczne do produktów, wobec których zastosowanie znajdą przepisy dyrektywy 85/374/EWG, w przypadku wyrządzenia przez ich użycie szkody. Polska judykatura wypracowała pod tym względem tożsa-

17 Pełna treść wyroku Trybunału z dnia 2 grudnia 2009 r., C - 358/08 - dostępna na: http://curia.europa.eu/juris/liste.jsf?language=pl\&jur=C,T,F\&num=358/08\&td=ALL 
me stanowisko ${ }^{18}$, co skutkuje możliwością zastosowania wobec producenta (a także dystrybutora, importera, dostawcy) leku przepisów prawnych, zawartych w Tytule VI ${ }^{1}$ Księgi III Kodeksu cywilnego ${ }^{19}$. Zgodnie z art. $449^{1}$ $\S 2$ k.c. przez produkt rozumie się, co do zasady, rzecz ruchomą, a więc samoistny przedmiot materialny, choćby został on połączony z inną rzeczą. Środki farmaceutyczne będą niewątpliwie samoistnymi przedmiotami materialnymi, a więc rzeczami ruchomymi. Będą one zawsze wytworem działalności człowieka, co milcząco zakłada implementowana dyrektywa, posługująca się pojęciem „produktu”, a więc wytworu działalności ludzkiej za którego bezpieczeństwo ponosi się odpowiedzialność, nawet jeżeli stopień przetworzenia jest niewielki. Środki farmaceutyczne są rzeczami ruchomymi w powyższym rozumieniu. Tym samym przepisy dyrektywy 85/374/EWG będą miały, od strony przedmiotowej, pełne zastosowanie do środków farmaceutycznych. ${ }^{20}$

Zgodnie z treścią art. 11 dyrektywy 85/374/EWG „Państwa Członkowskie zagwarantuja w swoim ustawodawstwie, że prawa przyznane osobie poszkodowanej zgodnie z przepisami niniejszej dyrektywy, wygasaja po uptywie okresu 10 lat od daty wprowadzenia przez producenta do obrotu produktu, który spowodowat szkodę, chyba że osoba poszkodowana wszczęła przed uptywem tego terminu postępowanie przeciwko producentowi". W wyroku z dnia 2 grudnia 2009 roku, w sprawie o sygn. akt: C - 358/08, Trybunał wskazał, że po upływie okresu przedawnienia nie ma możliwości wstąpienia do toczącego się postępowania producenta produktu, wskazanego w art. 3 dyrektywy 85/374, którym jest wytwórca gotowego produktu oraz jego części składowych, jak również podmiot, który umieszcza swój znak towarowy na produkcie i podaje się za producenta. W przypadku, gdy producent nie jest znany, zgodnie z treścia art. 3 ust. 3 dyrektywy 85/374/EWG odpowiedzialność spoczywa także na dostawcy lub importerze produktu.

${ }_{18}$ M. Nesterowicz, Odpowiedzialność cywilna za szkody wyrządzone przez leki, [w:] Studia z prawa cywilnego i gospodarczego. Księga pamiątkowa dedykowana Profesor Czesławie Żuławskiej, Kraków 2006, s. 182.

${ }^{19} \mathrm{H}$. Tuchołka, Odpowiedzialność za szkody wyrzadzone przez wytwarzane, importowane i wprowadzane na Polski rynek środki farmaceutyczne, „Prawo i Medycyna” 2001, nr 9, s. 88; M. Chajda, Przesłanki odpowiedzialności za szkody wyrządzone przez leki jako produkty niebezpieczne, [w:] M. Załucki (red.) Rozwój prawa własności intelektualnej w sektorze farmaceutycznym, Warszawa 2010, s. 2.

${ }^{20}$ D. Gęsicka, Odpowiedzialność za szkody wyrządzone przez produkty lecznicze - zagadnienia wybrane, „Prawo i Medycyna” 2013, nr 3 - 4, ss. 191 - 194. 
Należy zauważyć, że Z. Gawlik przedstawił interesującą koncepcję dotyczącą liczenia terminu przedawnienia, która jest jak najbardziej zasadna, gdyż przedstawiona przez niego argumentacja skłania autora artykułu do jej przyjęcia. W jej ramach zostało wskazane m.in., że: „(...) chwila wprowadzenia produktu do obrotu nie oznacza, iż jest »tyle chwil « wprowadzenia produktu do obrotu, ile jest produktów w obrocie. Chwila wprowadzenia produktu do obrotu powinna być odnoszona do pewnego produktu określonego gatunkowo, $z$ tożsamymi znamionami danego modelu. Producent podejmuje zamyst wprowadzenia produktu do obrotu nie w odniesieniu do jednostkowej rzeczy, ale takie decyzje o zamiarze wprowadzenia do obrotu dotycza określonej grupy produktów"21. Oznacza to, że termin przedawnienia niejest liczony od dnia wprowadzenia danego, jednostkowo produktu na rynek, lecz całego gatunkowo wyprodukowanego produktu. Dodać można jedynie, że dopiero w sytuacji, gdyby producent wytworzył produkt na indywidualne zamówienie, wówczas z uwagi na to, że cechy charakterystyczne dla tego „modelu” będzie miała tylko ta jedna rzecz, wyjątkowo prawnie relewantny będzie tu moment wprowadzenia jej jednej do obrotu ${ }^{22}$.

Choć nie sposób polemizować z trafnością analizowanego orzeczenia Trybunału, to jednak należy zwrócić uwagę, przede wszystkim na dwie wyjątkowe sytuacje, które „przełamują" zakaz wstąpienia ustanowionego, „producenta” w rozumieniu art. 3 tej dyrektywy, w miejsce strony pozwanej do postępowania sądowego wszczętego w tym terminie przeciwko innemu podmiotowi.

Pierwszy przypadek dotyczy sytuacji, gdy postępowanie „odszkodowawcze" zostało wszczęte przez poszkodowanego wobec spółki, która jest w 100 \% zależna od producenta. Producent taki ma możliwość wstąpienia do toczącego się postępowania pomimo upływu terminu przedawnienia, wskazanego w art. 11 dyrektywy 85/374/EWG pod warunkiem, że sąd uzna, że towar został faktycznie przez niego wprowadzony do obrotu.

Trzeba wskazać że zależność pomiędzy jedną spółka, a drugą należy oceniać na gruncie przepisów prawa krajowego - członka UE, w którym jest rozpatrywana tożsama sprawa, a to w związku z faktem, że prawo unijne nie zawiera definicji legalnej spółki zależnej. Przekładając opisa-

${ }^{21}$ Z. Gawlik, [w:] A. Kidyba (red.), Kodeks cywilny. Komentarz, t. III, Zobowiązania. Część ogólna, Warszawa 2010, s. 52.

${ }^{22}$ J. Kuźmicka - Sulikowska, Pojęcie produktu niebezpiecznego na gruncie przepisów kodeksu cywilnego dotyczacych odpowiedzialności za szkodę wyrządzona przez ten produkt, [w:] J. Mazurkiewicz (red.) Księga dla naszych kolegów, Wrocław 2013, s. 259. 
ną sytuację na grunt ustawodawstwa polskiego, to w celu określenia zależności pomiędzy ww. spółkami posłużylibyśmy się przepisem ustawy z dnia 15 września 2000 r. - Kodeksu spółek handlowych ${ }^{23}$, tj. art. 4 § 1 pkt 4 k.s.h., który definiuje pojęcie „spółki dominującej”. Pomocniczo można wykorzystać:

- ustawę z dnia 29 lipca 2005r. o ofercie publicznej i warunkach wprowadzania instrumentów finansowych do zorganizowanego systemu obrotu oraz o spółkach publicznych ${ }^{24}$, bądź

- ustawę z dnia 29 września 1994 roku o rachunkowości ${ }^{25}$,

które również zawierają definicję legalne spółki dominującej (spółki zależnej), aczkolwiek stosowanie art. 4 § 1 pkt 4 k.s.h. wydaje się najwłaściwszym rozwiązaniem.

Wyrok Trybunału w przedmiotowej sprawie, zawiera sformułowanie „producent może wstapić w miejsce tej spótki ...". W związku z powyższym, należy dokonać analizy sytuacji, dotyczącej niewstąpienia producenta produktu niebezpiecznego do toczącego się postępowania sądowego. W obecnym stanie prawnym nie sposób udzielić jednoznacznej odpowiedzi, gdyż ani orzecznictwo ani judykatura europejska nie wypracowały stanowiska do takiej sytuacji. Jednakże należałoby przyjąć, że zastosowanie będą miały przepisy prawa krajowego, w którym takowa sprawa będzie rozpoznawana. W przypadku procedowania przed sądem polskim, należałoby zastosować przepisy ustawy z dnia 17 listopada 1964 - Kodeks postępowania cywilnego ${ }^{26}$, tj. art. 194 k.p.c. w zw. z art. 198 k.p.c., które pozwalają na zawezwanie innej osoby fizycznej, osoby prawnej bądź jednostki organizacyjnej nieposiadającej osobowości prawnej do udziału w postępowaniu sądowym, a w związku z tym, w przedmiotowej sprawie istnieje możliwości zawezwania rzeczywistego producenta produktu niebezpiecznego. Należy podkreślić, że podmiotowa zmiana powództwa po stronie pozwanej może nastąpić nie tylko na wniosek powoda, lecz także, gdy powództwo zostało wniesione przeciwko osobie, która nie powinna

${ }^{23}$ Ustawa z dnia 15 września 2000 r. - Kodeks spółek handlowych, Dz. U. Nr 94, poz. 1037 z późn. zm.

${ }^{24}$ Ustawa z dnia 29 lipca 2005 r. o ofercie publicznej i warunkach wprowadzania instrumentów finansowych do zorganizowanego systemu obrotu oraz o spółkach publicznych, Dz.U. 2005 Nr 184 poz. 1539 z późn. zm.

${ }^{25}$ Ustawa z dnia 29 września 1994 r. o rachunkowości, Dz.U. 1994 Nr 121 poz. 591. z późn. zm.

${ }^{26}$ Ustawa z dnia 17 listopada 1964 r. - Kodeks postępowania cywilnego, Dz.U. Nr 43, poz. 296. z późn. zm. 
być w sprawie stroną pozwaną - także na wniosek pozwanego. Dopozwanie na wniosek pozwanego stanowi natomiast środek jego obrony, gdyż $\mathrm{w}$ ten sposób pozwany zmierza do ustąpienia z procesu, jednocześnie wskazując inną osobę, przeciwko której powinien zapaść wyrok uwzględniający żądanie powoda. Jeżeli $\mathrm{z}$ wnioskiem o wezwanie do udziału w sprawie występował pozwany, to skutki wytoczenia powództwa wobec nowego podmiotu powstaną dopiero z momentem wydania przez sąd postanowienia uwzględniającego wniosek o dopozwanie. Z kolei skutki, jakie ustawa wiąże $\mathrm{z}$ doręczeniem pozwu pozwanemu, powstaną wobec dopozwanego zawsze z momentem doręczenia mu postanowienia o dopozwaniu wraz z odpisem pozwu wniesionego w sprawie ${ }^{27}$.

Dopozwany za zgodą obu stron może wstąpić w miejsce dotychczasowego pozwanego, który w ten sposób będzie zwolniony od dalszego udziału w toczącym się postępowaniu. Dotyczy to jednak tylko tej osoby, która została wezwana do udziału w sprawie z uwagi na brak legitymacji biernej pozwanego oznaczonego w pozwie (art. $194 \S 1$ k.p.c.). Tego typu przekształcenie prowadzi do sukcesji procesowej, w ramach której dopozwany wstępuje w sytuację procesową swojego poprzednika. Oznacza to, że skutki jakie ustawa wiąże z wytoczeniem powództwa i doręczeniem pozwu pozwanemu, odnoszą się do osoby wezwanej do udziału w sprawie od tego samego momentu, od którego wiązały pierwotnego pozwanego. Wstąpienie osoby dopozwanej w miejsce pozwanego, który ustępuje z procesu, nie wymaga żadnej decyzji procesowej sądu ${ }^{28}$.

Drugi przypadek dotyczy sytuacji, gdy poszkodowany nie ma możliwości ustalenia tożsamości producenta produktu, co skutkuje, że powództwo zostanie wytoczone wobec dostawcy, który nie poinformował powoda z własnej inicjatywy i w staranny sposób o tożsamości producenta lub swojego dostawcy. W związku z powyższym, ulegają ziszczeniu przesłanki do stosowania treści art. 3 pkt 3 dyrektywy 85/374/EWG, tj. „W przypadku gdy producenta produktu nie można zidentyfikować, każdy dostawca produktu będzie traktowany jak jego producent, chyba że poinformuje osobe poszkodowana w rozsadnym terminie o tożsamości producenta lub osoby, która dostarczyła mu produkt. To samo stosuje się w przypadku produktu przywożonego, jeżeli brak na nim wskazania tożsamości importera, określonego w ust. 2, nawet jeżeli

27 E. Rudkowska - Ząbczyk, Komentarz do art. 194 k.p.c., [w:] E. Marszałkowska-Krześ (red.), Kodeks Postępowania Cywilnego. Komentarz, Warszawa 2015, s. 456.

${ }^{28}$ Tamże. 
nazwa producenta jest wskazana". Tym samym, dostawcy zostanie przypisana odpowiedzialność, chyba, że poinformuje poszkodowanego w rozsądnym terminie o tożsamości producenta lub osoby, która dostarczyła mu produkt. Nadto wypada podkreślić, że poszkodowany nie ma prawnego obowiązku poszukiwania wszystkimi sposobami producenta, jeśli nie może takowego w normalny sposób zidentyfikować. Trzeba zwrócić uwagę, że dyrektywa 85/374/EWG nie zawiera wyjaśnienia pojęcia „w rozsadnym terminie", a judykatura i orzecznictwo europejskie nie wypracowały stanowiska w tym przedmiocie. W związku z powyższym, należy stosować przepisy ustawodawstwa krajowego państwa członkowskiego UE, w którym to będzie rozpatrywana takowa sprawa. Polskie prawo również nie zawiera wyczerpującego wyjaśnienia pojęcia "rozsądny termin". Można więc zastosować wykładnię językową bądź posłużyć się pomocniczo orzeczeniami Sądów polskich w podobnych sprawach, aczkolwiek należy pamiętać, że sąd polski ma obowiązek zastosowania treści art. 207 par 2 k.p.c., zgodnie z którym: Przewodniczacy może zarządzić wniesienie odpowiedzi na pozew w wyznaczonym terminie, nie krótszym niż dwa tygodnie. W terminie wskazanym przez sąd, pozwany (dostawca) w odpowiedzi na pozew, może wskazać faktycznego producenta produktu bądź swojego dostawcę. Brak udzielenia odpowiedzi w zakreślonym przez sąd terminie, odnośnie wskazania rzeczywistego producenta może przynieść negatywne konsekwencje dla pozwanego (dostawcy), nawet poprzez uwzględnienie przez sąd powództwa w całości.

Należy zwrócić uwagę, że w orzecznictwie przyjmuje się, że "Odpowiedzialność za szkode wyrządzona przez produkt niebezpieczny na podstawie art. $449^{5} \S 2$ k.c. ponosić może tylko podmiot, który jest rzeczywistym importerem danego produktu, względnie który oznakował w sposób wskazany w tym przepisie produkt." ${ }^{\prime 29} \mathrm{~W}$ cytowanej sprawie, pozwana spółka nie była importerem produktu niebezpiecznego oraz nie oznaczyła go jako importowanego przez siebie, a podczas trwania postępowania przed sądem I instancji, jak również przed sądem odwoławczym podnosiła wspomniane argumenty, co skutkowało oddaleniem przez sąd powództwa. Sytuacja byłaby odmienna, gdyby pozwana spółka nie wdała się w spór merytoryczny ze stroną powodowa, a przyjęłaby postawę bierną, co zakończyłoby się najprawdopodobniej uwzględnieniem w całości powództwa.

${ }^{29}$ Wyrok SA w Poznaniu z dnia 10 sierpnia 2011 roku, I ACa 571/11, LEX 1133341. 


\section{Wyrok Trybunału z dnia 21 grudnia 2011 r., w sprawie o sygn. akt: C-495/10 30}

\section{1.) Stan faktyczny rozpoznawanej sprawy i stawiane pytanie:}

Przedmiotowa sprawa dotyczy małoletniego Dutrueux, który podczas operacji chirurgicznej przeprowadzonej w dniu 3 października 2000 r. w CHU w Besançon uległ poparzeniom spowodowanym wadliwościa systemu regulacji ciepła w podgrzewanym materacu, na którym został ułożony. 27 marca 2007roku Sad administracyjny w Besançon zobowiazał CHU w Besançon do naprawienia wyrzadzonej w ten sposób T. Dutrueux'mu szkody. Po tym jak wyrokiem z dnia 26 lutego 2009 r. apelacja od tego wyroku została oddalona przez Sad apelacyjny w Nancy, CHU w Besançon wnióst od tej decyzji skarge kasacyjna do Conseil d'État. Na poparcie skargi kasacyjnej CHU w Besançon utrzymuje, że wyrok cour administrative d'appel de Nancy jest sprzeczny z dyrektywa 85/374, w szczególności zaś z art. 13 tej dyrektywy, ponieważ orzeczono w nim, że wspomniana dyrektywa nie stoi na przeszkodzie zastosowaniu wypracowanej $w$ orzecznictwie zasady, zgodnie z która publiczna stużba szpitalna ponosi odpowiedzialność, nawet w przypadku braku winy z jej strony, za szkody wynikłe dla użytkowników z wadliwości wykorzystywanych przez nich przy udzielaniu świadczeń opieki zdrowotnej produktów i urzadzeń. Z omawianej dyrektywy, $w$ postaci, w jakiej została transponowana do wewnętrznego prawa francuskiego, wynika bowiem zdaniem CHU w Besançon, że producent materaca powinien ponosić wyłaczna odpowiedzialność, jeżeli tylko, jak to miało miejsce w niniejszym przypadku, można go było zidentyfikować - treść orzeczenia Trybunału z dnia z dnia 21 grudnia 2011 roku, sygn.: C - 495/10.

W związku z powyższym, Conseil d'État (Francja) postanowił zawiesić postępowanie i zwrócić się do Trybunału z następującymi pytaniami prejudycjalnymi:

"1) Czy zważywszy na postanowienie art. 13 dyrektywy [85/374], dyrektywa ta pozwala na ustanowienie systemu odpowiedzialności opartego na szczególnej sytuacji pacjentów publicznych zakładów opieki zdrowotnej, przyznającego pacjentom w szczególności prawo do uzyskania od tych zakładów, nawet w braku ich winy, naprawienia szkód spowodowanych wadliwościa wykorzystywanych przez

${ }^{30}$ Sprawa pomiędzy Centre hospitalier universitaire de Besançon przeciwko Thomasowi Dutrueux'mu, a dotycząca naruszenia art. 3 i 13 dyrektywy 85/374/EWG - odpowiedzialność za produkty wadliwe. 
nie produktów i urzadzeń, bez uszczerbku dla możliwości wniesienia przez zakład powództwa na podstawie gwarancji przeciwko producentowi?

2) Czy dyrektywa [85/374] ogranicza możliwość określenia przez państwa członkowskie odpowiedzialności osób, które w ramach świadczenia usług wykorzystuja wadliwe urządzenia lub produkty i w ten sposób powodują szkody u osób korzystających ze świadczenia?".

\section{2.) Streszczenie wyroku Trybunału:}

Odpowiedzialność usługodawcy, który w ramach świadczenia usług, takich jak świadczenia z zakresu opieki zdrowotnej udzielane w szpitalu, używa wadliwych urządzeń lub produktów, których nie jest on producentem w rozumieniu przepisów art. 3 dyrektywy 85/374/EWG, zmienionej dyrektywą 1999/34/WE Parlamentu Europejskiego i Rady z dnia 10 maja 1999 r. i wyrządza w związku z tym szkodę osobie korzystającej z tych świadczeń, nie jest objęta zakresem zastosowania wskazanej dyrektywy. Dyrektywa ta nie stoi więc na przeszkodzie ustanowieniu przez państwo członkowskie systemu, takiego jak system będący przedmiotem sporu przed sądem krajowym, przewidującego odpowiedzialność takiego usługodawcy za wyrządzone w ten sposób szkody, nawet jeżeli nie można mu przypisać jakiejkolwiek winy, pod warunkiem jednakże, że poszkodowany lub wspomniany usługodawca zachowają możliwość pociągnięcia producenta do odpowiedzialności na podstawie omawianej dyrektywy, jeżeli zostaną spełnione określone w niej przesłanki ${ }^{31}$.

\section{3.) Komentarz:}

Na wstępie należy podkreślić, że podgrzewany materac jest zaliczany do kategorii produktów określonych w art. 2 dyrektywy 85/374/EWG, a w związku z czym w przypadku jego wadliwego działania i wyrządzenia szkody, zastosowanie będą miały przepisy wspomnianej dyrektywy. Potwierdza to również polska judykatura, która wskazuje, że wyroby farmaceutyczne i medyczne sa produktami niebezpiecznymi. Do produktów niebez-

31 Pełna treść wyroku Trybunału z dnia 21 grudnia 2011 r., C-495/10 - dostępna na: http://curia.europa.eu/juris/liste.jsf?language=pl\&jur=C,T,F\&num=495/10\&td=ALL 
piecznych zaliczyć można również produkty lecznicze i produkty lecznicze weterynaryjne w rozumieniu Prawa farmaceutycznego ${ }^{32}$ oraz wyroby medyczne ${ }^{33}$, w odniesieniu do których dopuszczenie do obrotu zostało uregulowane przepisami ustawy z 20.4.2004 r. o wyrobach medycznych. ${ }^{34}$

Trybunał w wyroku z dnia 21 grudnia 2011 roku, w sprawie o sygn. akt: C-495/10, wskazał w sposób jednoznaczny, że „ustugodawca, który wyłacznie używa wadliwych urzadzeń lub produktów, których nie jest on producentem w rozumieniu przepisów art. 3 dyrektywy 85/374/EWG nie poniesie odpowiedzialności na gruncie przepisów zawartych w przedmiotowej dyrektywie." Trzeba podkreślić, że powyższy pogląd jest w pełni uzasadniony. Należy zwrócić uwagę, że przedmiotowe orzeczenie ma charakter uniwersalny. Uniwersalność wynika z faktu, że usługodawcą może być zarówno określony w przedmiotowej sprawie szpital, jak również każdy podmiot gospodarczy, który wyrządził szkodę poszkodowanemu, posługując się wyłącznie wadliwą rzecza, a niebędący jej producentem, czy dystrybutorem. Słusznie bowiem Trybunał zauważa, że prawo unijne, a przede wszystkim sama dyrektywa 85/374/EWG nie zawierają definicji legalnych "ustugodawcy" bądź ",dostawcy”, aczkolwiek na gruncie innych orzeczeń Trybunału, należy przyjąć, że za dostawcę rozumie się podmiot, który dostarczył wadliwy produkt, a za usługodawcę rozumie się podmiot, który świadczy daną usługę, korzystając z wadliwego produktu. W związku z powyższym nie ma podstaw, ani przesłanek prawnych do rozszerzenia stosowania postanowień przedmiotowej dyrektywy wobec usługodawcy. Trzeba w całości zaaprobować pogląd, że dyrektywa 85/374/EWG nie sprzeciwia się stosowaniu w prawie krajowym, takich przepisów, które umożliwią pociagniecie do odpowiedzialności usługodawcy, nawet jeśli nie można przypisać mu jakiejkolwiek winy, pod warunkiem jednakże, że poszkodowany lub wspomniany usługodawca zachowają możliwość pociągnięcia producenta do odpowiedzialności na podstawie omawianej dyrektywy, w sytuacji gdy zostaną spełnione określone w niej przesłanki.

W przypadku, gdy polskie prawo nie zawiera definicji danego pojęcia, to sąd jest zobowiązany dokonać wykładni danego słowa, w celu ustale-

${ }^{32}$ Ustawa z dnia 6 września 2001 r. - Prawo farmaceutyczne, Dz.U. Nr 126, poz. 1381 z późn. zm.

${ }_{33}$ G. Rączka, Komentarz do art. 51 ustawy prawo farmaceutyczne, [w:] L. Ogiegło (red.) Prawo farmaceutyczne, Warszawa 2015.

${ }^{34}$ Ustawa z dnia 20 maja 2010 r. o wyrobach medycznych, Dz. U. 2010 nr 107 poz. 679 z późn. zm. 
nia substratu danego pojęcia. Przykładowo w wyroku Sądu Najwyższego z dnia 26 czerwca 2013 roku, w sprawie o sygn. akt V CSK 366/12, została dokonana wykładnia celowościowa i językowa pojęcia „importer", tj. "Rozumienie wyrazu „importer" użytego w art. 20 ust. 1 ustawy z dnia 4 lutego 1994 r. o prawie autorskim i prawach pokrewnych powinno być wyjaśnione $w$ drodze przyjętych $w$ doktrynie i w orzecznictwie regut wykładni językowych, systemowych i funkcjonalnych. W ramach wykładni językowej wyróżnia się rozumienie danego pojęcia określone w słownikach języka polskiego jako powszechnie przyjmowane. W odniesieniu do zwrotu będacego terminem prawnym trzeba odwołać się w pierwszej kolejności do jego znaczenia w języku prawniczym - języku literatury prawniczej, języku orzecznictwa sadowego - dla danej gałęzi prawa, jeśli nie ma dla niego definicji legalnej w akcie prawnym, w którym zostat użyty, a następnie do powszechnego znaczenia językowego. W razie nieusunięcia watpliwości w określeniu znaczenia danego zwrotu również przy zastosowaniu tych regut, siegnać należy po dyrektywy interpretacyjne wykładni systemowej i celowościowej w obrębie danej dziedziny prawa." ${ }^{35}$.

Słownik języka polskiego PWN wskazuje, że za usługodawcę trzeba uznać osobę lub instytucję świadcząca usługi ${ }^{36}$. Można również wykorzystać szczątkowe regulacje, znajdujące się w innych ustawach, a tj. art. 279 ustawy z dnia 27 sierpnia 2009 r. o finansach publicznych ${ }^{37}$, który zawiera wyjaśnienie pojęcia usługodawca. W pewnym zakresie także art. $187^{1}$ k.p.c., definiuje usługodawcę, aczkolwiek dotyczy to sytuacji, gdy usługodawca ma zamiar wytoczyć powództwo w pewnych sprawach:

"Jeżeli powód będacy ustugodawca lub sprzedawca dochodzi roszczeń wynikajacych z umów o:

1) świadczenie ustug pocztowych i telekomunikacyjnych,

2) przewóz osób i bagażu w komunikacji masowej,

3) dostarczanie energii elektrycznej, gazu i oleju opałowego,

4) dostarczanie wody i odprowadzanie ścieków,

5) wywóz nieczystości,

6) dostarczanie energii cieplnej

- jest obowiazany wnieść pozew na urzędowym formularzu."

Konkludując należy wskazać, że Trybunał w wyroku z dnia 21 grudnia 2011 r., w sprawie o sygn. akt: C-495/10 słusznie uznał, że nie ma pod-

${ }^{35}$ Wyrok SN z dnia 26 czerwca 2013 r.,V CSK 366/12, LEX 1375503.

${ }^{36}$ L. Drabik, E. Sobol, Stownik języka polskiego PWN, Warszawa 2014, s. 561.

37 Ustawa z dnia 27 sierpnia 2009 r. o finansach publicznych, tekst jednolity, Dz. U. z 2016 r., poz.1870. 
staw prawnych do poniesienia odpowiedzialności prawnej (odszkodowawczej) przez usługodawcę na gruncie dyrektywy 85/374/EWG, gdyż nie jest on ani producentem, ani dystrybutorem, aczkolwiek Trybunał nie wykluczył, że istnieją podstawy prawne do pociągnięcia do odpowiedzialności usługodawcy na podstawie innych przepisów prawa cywilnego, np. na zasadach ogólnych lub za szkody wynikłe z niewykonania lub nienależytego wykonania zobowiązania bądź z tytułu rękojmi za wady i gwarancji jakości.

\section{Wnioski końcowe}

Każda z omawianych spraw była rozpoznawana przez Trybunał w tzw. postępowaniu prejudycjalnym, a tj. na wniosek sądu krajowego danego państwa, który na mocy dyspozycji art. 267 Traktatu o Funkcjonowaniu Unii Europejskiej ${ }^{38}$ zwrócił się do Trybunału o udzielenie odpowiedzi na przedstawione mu pytanie prejudycjalne dotyczące wykładni przepisów dyrektywy 85/374/EWG. Tryb prejudycjalny to postępowanie sądowe toczące się przed Trybunałem, a charakteryzuje się tym, że sąd państwa członkowskiego ma prawo zwrócić się w niektórych sytuacjach z zapytaniem do Trybunału, jeśli ma wątpliwości co do prawidłowego zastosowania prawa unijnego przy rozstrzyganiu konkretnej sprawy. Sąd krajowy państwa członkowskiego może skierować pytanie prejudycjalne, jeśli orzeczenie podlega zaskarżeniu, zaś gdy orzeczenie według prawa wewnętrznego nie podlega zaskarżeniu, sąd ma obowiązek zwrócić się do Trybunału z pytaniem prejudycjalnym, dotyczącym jego wykładni, jak i oceny ważności. ${ }^{39}$ Orzeczenia wstępne (prejudycjalne) posiadają moc prawnie wiążącą w takim sensie, że sądy krajowe państw członkowskich Unii Europejskiej muszą się do nich stosować bądź wystąpić z ponownym pytaniem prejudycjalnym, aczkolwiek obowiązek przestrzegania orzeczeń wstępnych nie wynika z żadnego z postanowień

38 Traktat z Lizbony zmieniający Traktat o Unii Europejskiej i Traktat ustanawiający Wspólnotę Europejską, sporządzony w Lizbonie dnia 13 grudnia 2007 r., Dz.U. 2009, Nr 203, poz. 1569.

${ }^{39}$ P. Konarska, Tryb prejudycjalny jako forma wspótpracy sądów krajowych z Trybunałem Sprawiedliwości, [w:] Prawo europejskie w praktyce, 2013, ss. 12 - 14. 
traktatowych, a jedynie ze stanowiska Trybunału ${ }^{40}$. W praktyce sądy krajowe w większości przypadków zaakceptowały moc wiążącą orzeczenia wstępnego wydanego na ich wniosek przez Trybunał, aczkolwiek odnotowano sporadyczne sytuacje, gdy sądy odmawiały zastosowania się do wydanego orzeczenia, powołując się na swoją autonomię proceduralną ${ }^{41}$ Zasada prawna dotycząca pełnej akceptacji orzeczeń prejudycjalnych, została określona w sprawie Milch-, Fett- und Eierkontor GmbH v. Hauptzollamt Saarbrücken, w której to Trybunał w sposób jednoznaczny wskazał, że „wyrok wydany przez ETS na podstawie art. 267 TUE (wcześniej art. 234 TWE) jest wiażący dla Sądu krajowego prowadzacego postępowanie w sprawie, której dotyczy orzeczenie" ${ }^{\prime 42}$. Wypada wskazać, że wysoki stopień uszczegółowienia orzeczenia Trybunału, ma ogromny wpływ na treść wyroku sądu krajowego,cowkonsekwencjimożedoprowadzićdotakiejsytuacji,żewspomniane orzeczenie stanowi pełne odzwierciedlenie orzeczenia Trybunału. Z drugiej strony, trzeba podkreślić, że Trybunał może tylko wskazać, które okoliczności trzeba uwzględnić przy rozpoznawaniu danej sprawy.

Należy zwrócić uwagę, że kwestia mocy wiążącej orzeczeń Trybunał była poruszana w wyroku Sądu Najwyższego z dnia 26 czerwca 2013 r., w sprawie o sygn. akt: V CSK 366/12: „Obowiazek prounijnej wykładni prawa krajowego wynika z art. 288 Traktatu o Funkcjonowaniu Unii Europejskiej (Dz. U. 2004 r. Nr 90, poz. 864), a zostat sformułowany $i$ doprecyzowany w orzecznictwie Trybunału Sprawiedliwości (wyrok z dnia 24 maja 2012 r., C - 97/11 Amia Sp. A w likwidacji przeciwko Provincia Regionale di Palermo, z dnia 24 stycznia 2012 r.; C-282/10 M. Dominguez przeciwko Centre informatique du Centre Ouest Atlantique, postanowienie Sądu Najwyższego z dnia 22 lipca 2007 r., IV CSK 200/06, OSNC 2008, nr 2, poz. 25). (...) Celem tego obowiazku jest zapewnienie, w ramach właściwości sadu krajowego, pełnej skuteczności prawa Unii przy rozpoznawaniu zawistych sporów, w drodze odpowiedniej, najczęściej funkcjonalnej wykładni prawa krajowego. Taka wykładnia wpływa na rozumienie przepisów krajowych, może prowadzić do zmiany znaczenia nieostrych pojęć, a także modyfikacji dotychczasowej linii orzecznictwa (uchwały Sądu Najwyższego z dnia 21 listopada 2012 r., III PZP 6/12, OSNP 2013, nr

${ }^{40}$ M. Koszowski, Granice związania orzecznictwem Trybunału Sprawiedliwości Unii Europejskiej, [w:] S.M. Grochalski (red.), Granice państwa jako granice jurysdykcji w Unii Europejskiej, Dąbrowa Górnicza 2012, s. 35-54.

${ }^{41}$ P. Dąbrowska, Skutki orzeczenia wstępnego Europejskiego Trybunatu Sprawiedliwości, Warszawa 2004, s. 48.

${ }^{42}$ Pełna treść wyroku Trybunału z dnia 24 czerwca 1969 r., C-29/68, ECLI:EU:C:1969:27. 
13 - 14, poz. 146 i z dnia 19 listopada 2010 r., III CZP 79/10, OSNC 2011, nr 4, poz. 41). Może również dojść do odmowy zastosowania przepisów krajowych, ale przed podjęciem decyzji w tej kwestii, sąd powinien ustalić, z uwzględnieniem nie tylko tych przepisów, ale także wszystkich przepisów prawa wewnętrznego i przy zastosowaniu metod wykładni uznanych w tym porzadku prawnym, czy nie uda się dokonać wykładni prawa krajowego, która byłaby zgodna z brzmieniem i celami dyrektywy. Jeżeli taka wykładnia nie jest możliwa, sąd krajowy nie powinien stosować przepisów krajowych sprzecznych z dyrektywą. Dotyczy to przede wszystkim spraw, w których sad stosuje przepisy wdrażajace dyrektywe i stwierdzi występowanie niezgodności między znajdującymi zastosowanie do rozstrzygnięcia sprawy przepisami prawa polskiego a przepisami prawa unijnego oraz gdy sąd stosuje przepisy prawa polskiego, które wprowadzaja instytucje $i$ normy prawa unijnego, przewidziane w aktach unijnego prawa pochodnego"43.

Zgodnie z art. 4 Traktatu o Unii Europejskiej oraz art. 288 Traktatu o Funkcjonowaniu Unii Europejskiej państwa członkowskie UE zostają zobowiązane do implementacji określonych regulacji prawnych, służących osiągnięciu wskazanego w danej dyrektywie, pożądanego stanu rzeczy. Analogiczna sytuacja dotyczyła również implementacji dyrektywy 85/374/EWG do porządków prawnych państw członkowskich. Sąd krajowy rozpoznający sprawę dotycząca odpowiedzialności prawnej za szkodę wyrządzoną przez produkt wadliwy (niebezpieczny), stosuje postanowienia „implementowanej” dyrektywy 85/374/EWG, aczkolwiek samo procedowanie, odbywa się na mocy przepisów krajowej procedury cywilnej. Wynika to z faktu, że po dzień dzisiejszy nie doszło do uchwalenia ujednoliconego europejskiego kodeksu postępowania cywilnego, tak jak również kodeksu postępowania karnego, aczkolwiek występują zalążki ujednoliconych przepisów $\mathrm{m}$. in. europejskie postępowanie w sprawie drobnych roszczeń w polskim kodeksie postępowania cywilnego bądź wystąpienie państwa członkowskiego Unii Europejskiej o przekazanie osoby ściganej na podstawie europejskiego nakazu aresztowania $\mathrm{w}$ polskim kodeksie postępowania karnego.

W analizowanych sprawach, Trybunał wydał orzeczenia, udzieliwszy odpowiedzi na stawiane mu pytania prejudycjalne, dokonując wykładni przepisów dyrektywy 85/374/EWG. Celem przedmiotowego artykułu było wskazanie, że w przypadku rozpoznawania przez sądy krajowe

${ }^{43}$ Wyrok SN z dnia 26 czerwca 2013 r., V CSK 366/12, Legalis 743814. 
podobnych spraw co analizowane, należy stosować jako źródło prawa materialnego przepisy „implementowanej dyrektyw 85/374/EWG” do Kodeksu cywilnego oraz dorobek orzeczniczy Trybunału, aczkolwiek samo procedowanie będzie opierało się na przepisach krajowego Kodeksu postępowania cywilnego. W komentarzu do każdego z analizowanych orzeczeń Trybunału, przedstawiono zakres stosowania polskiej procedury cywilnej wraz ze wskazaniem, jakie przepisy postępowania cywilnego powinny znaleźć zastosowanie $\mathrm{w}$ przypadku rozpoznawania podobnych spraw przez sądy polskie.

Należy zwrócić uwagę, że dorobek orzeczniczy Trybunału Sprawiedliwości w kwestiach dotyczących odpowiedzialności producenta za wyrób niebezpieczny ulega systematycznemu poszerzeniu. W połączonych sprawach AOK Sachsen-Anhalt - Die Gesundheitskasse oraz Betriebskrankenkasse Trybunał uznał że, zgodnie z art. 6 ust 1 dyrektywy 85/374/EWG produkt jest wadliwy jeśli nie zapewnia bezpieczeństwa jakiego można oczekiwać, biorąc pod uwagę, $\mathrm{m}$.in. wygląd produktu, sposób jego użycia oraz czas w jaki został do obrotu. W stosunku do wyrobów medycznych z uwagi na ich funkcję i szczególną wrażliwość wymogi bezpieczeństwa, są szczególnie wysokie. W związ$\mathrm{ku} \mathrm{z}$ powyższym stwierdzenie potencjalnej wady takich należących do tej samej grupy lub serii produkcyjnej produktów pozwala uznać za wadliwe wszystkie należące do owej grupy lub serii produkty bez konieczności wykazania wady danego konkretnego produktu. Zgodnie z treścią wyroku należy przyjąć, że naprawienie szkody obejmuje zatem wszystko, co jest konieczne do usunięcia szkodliwych konsekwencji oraz do przywrócenia poziomu bezpieczeństwa, którego można oczekiwać ${ }^{44}$.

Analiza wskazanych orzeczeń Trybunału a zarazem specyfika implementowanej dyrektywy 85/374/EWG potwierdzają że dyrektywa jest wciąż jedynym narzędziem stwarzającym realne możliwości wystąpienia $\mathrm{z}$ roszczeniem i uzyskaniem odszkodowania adekwatnego do rozmiaru szkody poniesionej z tytułu wadliwych produktów. Z treści wyroku Sądu Najwyższego z dnia 26 czerwca 2013 r., w sprawie o sygn. akt: V CSK 366/12 wynika, że w polskim porząd$\mathrm{ku}$ prawnym obowiązuje zasada prounijnej wykładni przepisów i orzeczeń europejskich, co skutkuje tym, że wyroki wydawane przez

${ }^{44}$ Pełna treść wyroku Trybunału z dnia 5 marca 2015 r., C-503/13 i C-504/13 Legalis 1281413. 
polskie sądy de facto i de iure odzwierciadlają treść orzeczeń wydanych przez Trybunału. Należy zwrócić uwagę, że po dzień dzisiejszy nie ukształtował się w materii dotyczącej art. $449^{1}-449^{11}$ k.c. odpowiedni dorobek judykatury, co powoduje pewne trudności orzecznicze. Jak wynika z przeprowadzonych rozważań, wiele kontrowersji powoduje zagadnienie związane z samym sprecyzowaniem, jak mają procedować sądy, które rozpatrują daną sprawę z uwzględnieniem przepisów Kodeksu postępowania cywilnego i Kodeksu cywilnego, przy uwzględnieniu wiążącego orzecznictwa europejskiego. Nie ulega wątpliwości, że część niejasności podnoszonych $\mathrm{w}$ odniesieniu do regulacji odpowiedzialności za szkodę wyrządzoną przez produkt niebezpieczny funkcjonującej $\mathrm{w}$ ramach polskiego kodeksu cywilnego stanowi w istocie przeniesienie kontrowersji dotyczących przyjęcia pewnych rozwiązań w dyrektywie 85/374/EWG. Z drugiej jednak strony zauważyć należy, że w wielu kwestiach problemy interpretacyjne i niejasności wynikają z nieprawidłowego dokonania implementacji tej dyrektywy.

Wnioski de lege ferenda płynące $\mathrm{z}$ treści niniejszego artykułu wskazują że każdy prawnik mający w praktyce do czynienia z przepisami art. $449^{1}$ - $449^{11}$ k.c., a tj. dotyczącymi odpowiedzialności prawnej za szkodę wyrządzoną przez produkt niebezpieczny jest zobowiązany do wzięcia pod uwagę orzecznictwa Trybunału. Ponadto w każdym kraju członkowskim UE, występują odmienne przepisy postępowania cywilnego, co skutkuje, że sądy krajowe rozpatrujące tożsame sprawy mogą wydać odmienne wyroki, pomimo faktu, że orzekają na podstawie „implementowanej dyrektywy 85/374/EWG, a w związku z powyższym, w celu zapewnienia jednolitej linii orzeczniczej sądów krajowych należałoby zastanowić się nad ustanowieniem uniwersalnych, a tj. unijnych przepisów postępowania cywilnego, jeśli tylko takowa kompetencja przysługiwałyby organom Unii Europejskiej, co na dzień dzisiejszy jest wątpliwe.

Słowa kluczowe: produkt niebezpieczny, dyrektywa 85/374/EWG, orzecznictwo Trybunału Sprawiedliwości 


\section{Bibliografia:}

Bieniek G., Ciepła H., Dmowski S., Gudowski J., Kołakowski K., Sychowicz M., Wiśniewski T., Żuławska C. (red.), Komentarz do Kodeksu cywilnego. Księga trzecia. Zobowiązania, Warszawa 2011.

Chajda M., Przesłanki odpowiedzialności za szkody wyrzadzone przez leki jako produkty niebezpieczne, [w:] M. Załucki (red.) Rozwój prawa własności intelektualnej w sektorze farmaceutycznym, Warszawa 2010.

Chańko P., Przestanki odpowiedzialności deliktowej producenta za produkt niebezpieczny - orzecznictwo SN, "Monitor Prawniczy” 2010, nr 16.

Dąbrowska P., Skutki orzeczenia wstepnego Europejskiego Trybunału Sprawiedliwości, Warszawa 2004.

Drabik L., Sobol E., Słownik języka polskiego PWN, Warszawa 2014.

Gęsicka D., Odpowiedzialność za szkody wyrzadzone przez produkty lecznicze - zagadnienia wybrane, „Prawo i Medycyna” 2013, nr 3 - 4.

Gnela B., Odpowiedzialność Przedsiębiorców za szkody wyrządzone przez produkt niebezpieczny, [w:] A. Śmieja (red.) Odpowiedzialność cywilna w obrocie gospodarczym, [w:] Prace Naukowe UE we Wrocławiu, Wrocław 2011, nr 203.

Jagielska M., Odpowiedzialność za produkt, Kraków 1999.

Jagielska M., Podstawy odpowiedzialności za produkt, Warszawa 2004.

Kidyba A. (red.), Kodeks cywilny. Komentarz, t. III, Zobowiązania. Czesść ogólna, Warszawa 2010.

Konarska P., Tryb prejudycjalny jako forma wspótpracy sądów krajowych $z$ Trybunałem Sprawiedliwości, [w:] Prawo europejskie w praktyce, 2014, nr 12.

Koszowski M., Granice związania orzecznictwem Trybunału Sprawiedliwości Unii Europejskiej,[w:]S.M. Grochalski(red.) Granicepaństwajakogranicejurysdykcji w Unii Europejskiej, Dąbrowa Górnicza 2012.

Kuźmicka - Sulikowska J., Pojęcie produktu niebezpiecznego na gruncie przepisów kodeksu cywilnego dotyczacych odpowiedzialności za szkodę wyrządzona przez ten produkt, [w:] J. Mazurkiewicz (red.), Księga dla naszych kolegów, Wrocław 2013.

Łazowski A., Bezpieczeństwo produktu, „Gazeta Prawna” 1999, nr 41.

Łazowski A., Ogólne bezpieczeństwo i odpowiedzialność za produkt wadliwy, Warszawa 2001.

Łętowska E., Ochrona niektórych praw konsumentów. Komentarz, Warszawa 2001.

Marszałkowska - Krześ E. (red.), Kodeks Postepowania Cywilnego. Komentarz, Warszawa 2015.

Nesterowicz M., Odpowiedzialność cywilna za szkody wyrządzone przez leki, [w:] Studia z prawa cywilnego i gospodarczego. Księga pamiatkowa dedykowana Profesor Czesławie Zuławskiej, Kraków 2000.

Osajda K. (red.), Kodeks Cywilny. Komentarz. Zobowiazania, t. II, Warszawa 2014. 
Rączka G., Komentarz do art. 51 ustawy prawo farmaceutyczne, [w:] L. Ogiegło (red.) Prawo farmaceutyczne, Warszawa 2015.

Strus Z., Odpowiedzialność za szkode wyrzadzona przez produkt niebezpieczny, „Palestra” 2001, nr $1-2$.

Tuchołka H., Odpowiedzialność za szkody wyrzadzone przez wytwarzane, importowane $i$ wprowadzane na Polski rynek środki farmaceutyczne, „Prawo i Medycyna" 2001, nr 9.

\section{LEGAL LIABILITY OF PRODUCERS \\ FOR DAMAGE CAUSED BY DANGEROUS PRODUCTS \\ IN THE CASE LAWS OF THE COURT OF JUSTICE \\ AND POLISH LAW}

\section{S u m m a r y}

Along with the technological and economic development for the European and Polish market gets more and more products, whose main task is to improve the everyday life of society, but the quality of these products is diverse, resulting in occasionally damage occurred in people using the product. The purpose of this article is to present the liability of producers for damage caused by dangerous products, including judgments of the Court of Justice of the EU and Polish Courts. In the beginning, it was presented a historical review for a directive 85/374 / EEC with regard to its implementation to the Civil Code. In the following chapters it was made analysis of judgments of the Court of Justice of the EU, taking into account the provisions of Polish law. At the end of the final conclusion are listed recap the analysis of the Court's decisions.

Key words: dangerous products, Directive 85/374 / EEC, the case laws of the Court of Justice

\section{ЮРИДИЧЕСКАЯ ОТВЕТСТВЕННОСТЬ ПРОИЗВОДИТЕДЕЙ ЗА ВРЕД, ПРИЧЕНЕННЫЙ ОПАСНЫМ ТОВАРОМ В РЕШЕНИЯХ СУДА ЕВРОПЕЙСКОГО СОЮЗА И В ПОЛЬСКОМ ПРАВЕ}

$$
\text { P е } 3 \text { ю м е }
$$

Вместе с технологическим и экономическим развитием на европейском и подьском рынке попадается еще больше товаров, главным заданием которых является улучшением повседневной жизнь общества, но качество этих товаров разное, что в последствии возникает, в одиночных случаях, вред у лиц, которые используют данный товар. Цель данной статьи состоит в том, чтобы представить юридическую ответственность 
производителей за вред, причиненный опасным товаром, с учетом решений Суда Европейского Союза и польских судов. В начале, был переставлен исторический очерк, касательно директивы 85/374/EWG и с учетом реализации ее к гражданскому кодексу. В следующих разделах были проанализированные решения Суда Европейского Союза, с учетом положений подьского законодательства. В конце переданы выводы, которые включают анализ решений Суда.

Кдючивые слова: опасный товар, директива 85/374/EWG, решения Суда Европейского Союза. 